\title{
Role of Bhallatak Guggulu in the Management of Amavata (Rheumatoid Arthritis)
}

\author{
Research Article
}

\section{Shiv Shankar Shukla ${ }^{*}$, Astha Sharma ${ }^{2}$}

\section{Assistant Professor, Department of Sharir Kriya, Government Ayurvedic College, Burhanpur, MP 2. PG Scholar, Department of Swasthavritta, National Institute of Ayurveda, Jaipur.}

\begin{abstract}
Background and objectives: - Amavata (Rheumatoid arthritis) is a most remarkable problem in the society in modern era. In Ayurveda, many approaches are in practice to treat Amavata but still it remains a challenging problem. Ayurveda considers ama as the root cause of disease amavata. Design: Double blind randomized interventional trial. Participants: age group of 20-60 yrs. Method: 60 patients were selected from OPD and IPD of A \& U Tibbia college and hospital, Delhi. They were randomly divided in two groups. Bhallatakadi Churna with guda in Group A and Bhallatak guggulu in Group B administered for three months of duration with follow up at every fifteen days. Outcome measures:- The assessment of efficacy of drug was made through scoring of clinical features and Laboratory parameters i. e. RA factor, ASO titre. Results: Present study reflects that both regimesBhallatak churna with guda and Bhallatak guggulu, have given very good relief in sign and symptoms of Amavat, but in group B who received Bhallatak Guggul showed faster and better improvement. Conclusion:- Bhallatak Guggulu is safe, beneficial and very effective in management of Amavata and also in Rheumatoid arthritis.
\end{abstract}

Keywords: Ama, Amavata, Ayurveda, Bhallatakadi Churna, Bhallatak guggulu, Guda, Rheumatoid Arthritis.

\section{Introduction:-}

Amavata is chronic systemic disease having painful multiple joint involvement. In Ayurveda Madhavakar(700AD) mentioned first the Amavata as a special disease entity and where ama as well as vata plays a predominant role in the samprapti (pathogenesis) of the disease (1). Rheumatoid arthritis is a chronic, progressive autoimmune arthropathy and is characterised by bilateral symmetrical involvement of joints with some systemic clinical menifestations. (2) Ayurveda is an ancient scientific medical knowledge in the world. So many Ayurvedic medicines had been described in Ayurveda for the treatment of Amavata (Rheumatoid arthritis). Amavata is a most remarkable problem in the society in modern era.

Ayurveda considers ama as the root cause of disease amavata. Ama is a mucoid, slimy substance caused due to the malfunctioning of digestive and metabolic mechanisms. This ama is detrimental to srotas(body channels) due to its clogging capacity. While circulating in body along with vata it produces this agonising disease called amavata, which is very

\section{*Corresponding Author:}

Shiv Shankar Shukla,

Assistant Professor, Department of Sharir Kriya,

Government Ayurvedic College,

Burhanpur, MP.

Email address: dr.ayursss@gmail.com difficult to treat, and if not treated, leads to angavaikalya (deformities). (3)

The prevalence rate of this disease is about 3\% with a male to female ratio of $1: 3$. It occurs throughout the world in all climates and ethnic groups.

The conceptual study on rheumatoid arthritis and amavata revealed that there is striking similarities between etiopathogenesis of RA and amavata, and it was found that basic pathology in RA is microvascular injury caused by inflammatory mediators, especially in synovium which is nothing srotavarodha and srotobhisyanda caused by ama in dhamanis of sleshma sthana specially sleshma dharana kala of joints.

Several dreadful diseases are prevalent in medical science. The scope for therapeutic measures is limited even after extreme advancement of the modern biomedical science. The rheumatological disorder is a group of diseases that has no specific medical management in any type of therapeutics. In spite of the description of multiple drug therapy on Amavata in different classics of Ayurveda, potential and durable results are not found due to non-removal of the basic cause. Hence, special emphasis should be put into searching for a standard and suitable drug for A mavata.

In ancient literature of Ayurveda specially in Vrihatrayi, various measures and medicinal preparations are described for treating articular diseases. The disease amavata is described elaborately for the first time by Madhav in seventh century only. Chakradutta has not only outlined the chikitsa siddhanta for the disease amavata for the first time but 
has also been described several preparations for treating the disease. Hence, Ayurvedic medicine i. e. Bhallatak guggulu yoga has been selected from Yogaratnakar for clinical evaluation on the management of Amavata (Rheumatoid arthritis).

The trial drug Bhallatak guggulu yoga conisits of four herbs i. e. Bhallatak, Guggulu, Haritaki and Krishna Tila. These herbs are not only excellent in doing deepana, and pachana functions but also comprising vyadhi nashak guna. (4)

These drugs also have anti- inflammatory, immune modulatory, anti- oxidant anti- arthritic and cartilage protective activity. (5)

In Ayurveda many approaches are in practice to treat amavata but still it remains a challenging problem. Hence, the study is planned for better management of Amavata patients with enhanced quality of life.

\section{Aims and Objectives}

The present research trial has been undertaken with the following objective.

To validate Ayurvedic concept of rheumatology on scientific lines

To evaluate efficacy of Bhallatak Guggulu Yoga in the management of Amavata.

To develop safe and cost effective Ayurvedic drug for Rheumatoid arthritis.

\section{Material and methods \\ Selection of cases}

Total 60 cases divided in to two groups equally.

Group A-This group of 30 patients were given Bhallatakadi churna with guda

Group B-This group of 30 patients were given Bhallatak Guggulu.

The drug for group A was given in dose of 2 . $5 \mathrm{gm}$ twice a day while Bhallatak guggul was given in the dose of $500 \mathrm{mg}$ TDS in group B.

\section{Source}

Patients for the present study were screened out from the O. P. D. and I. P. D. of Kayachikitsa Department of A \& U Tibbia College and Hospital, Karol Bagh, New Delhi.

Age Group: between 20-60 years were selected.

Study design: Double blind randomised interventional clinical trial.

\section{Inclusive criteria}

- Age-20-60 years

- Patients of Amavata (Rheumatoid Arthritis) fulfilling the criteria of Clinical symptoms of Amavata mentioned in Ayurvedic classics.

- Patient able to participate in the study and ready to follow the instruction and consent for three months.

Exclusive Criteria

- Age below 20 and above 60 .

- All complicated cases having any advanced deformity of rheumatoid arthritis.

- Having cardiac diseases, pulmonary tuberculosis and pregnant woman.

- Pittaja prakrati and summer season

\section{Criteria for assessment}

Subjective criteria:

The results of therapy were assessed on the basis of clinical features of the disease A mavata, which are mentioned in Ayurvedic classic. The scoring pattern adopted for assessment of clinical features is as follows:
(a) Angmarda (Bodyache)
$0=$ Absent
$1=$ Transiently present
$2=$ Present for long period
$3=$ Regular present
(b) Aruchi (loss of appetite)
$0=$ Absent
$1=$ Present but not complained
$2=$ Present and complained
$3=$ Distressing in social life

(c) Alasya (Listlessness)

$0=$ Absent

$1=$ Present but not effecting the life

$2=$ Present for such work which need more effort

$3=$ Present and effecting routine biological activity

(d) Gaurav (Heaviness of body and joints)

$0=$ Absent

$1=$ Present but not complained

$2=$ Present and complained

$3=$ Distressing in social life

(e) Trishna (thirst)

$0=$ Absent

$1=$ Only feeling

(f) Jvara (fever)

$0=$ Absent

$1=$ only feeling

$2=$ Temp. Above normal but $<100^{\circ} \mathrm{F}$

$3=$ Temp $>100^{\circ} \mathrm{F}$

(g) Apaki (Indigestion)

$0=$ Absent

$1=$ Only occasional and Transient

$2=$ Often and Transient

$3=$ Very often, presented with associated symptoms

(h)Sandhishool (Pain in joints)

$0=$ No pain

$1=$ Mild pain of bearable nature, comes occasionally

$2=$ Moderate pain, but no difficulty in joint movement

$3=$ Slight difficulty in joint movements due to pain

(i)Shoonta anganam

$0=$ No swelling

$1=$ Slight swelling

$2=$ Moderate swelling

$3=$ Severe swelling

(j) Sandhi graha (stiffness of the joints)

$0=$ no stiffness or stiffness lasts for $5 \mathrm{~min}$.

$1=5$ min to 1 hour 
$2=1$ to 2 hour

$3=>2$ hour

(k) Sparshasahayata (Tenderness of joints)

$0=$ No tenderness

$1=$ Subjective experience of tenderness

$2=$ Wincing of face on pressure

$3=$ Wincing of face with withdrawal of affected parts on pressure

$4=$ Resists to touch

\section{Objective Criteria: Normal range}

(a) RA factor(Rheumatoid arthritis factor) $0-20$ $\mathrm{micro} / \mathrm{ml}$

(b) ASO Titre (Anti streptolysin O) upto $200 \mathrm{IU}$

(c) CRP (C- Reactive protein) less than 1

\section{Observation and Results}

Out of 60 patients, maximum $85 \%$ patients were female, $36 \%$ patients in between the age of $5^{\text {th }}$ decade, $53 \%$ patients were hindu, 85\% patients were married, $56 \%$ were kapha pitta prakriti, 58\% were Kroora koshta and $61 \%$ patients were non vegeterians; $8 \%$ patients showed positive family history and $92 \%$ patients did not show any family history. Maximum $100 \%$ patients had involvement of proximal interphalangeal (hand), MCP and wrist joint involvement.

Effect of both Bhallatakadi churna with guda and Bhallatak guggulu on chief symptoms of Amavata is found to be statistically highly significant $(\mathrm{p}<0.001)$ (Table no-1). Also statistically highly significant $(\mathrm{p}<0$. 001) results were found on general syptoms such as sandhishoola, sandhigraha and sandhisparsha ashayata. (Table no-2).

Table No 1: Effect of drug on symptoms of Amavata

\begin{tabular}{|c|c|c|c|c|c|c|c|c|c|c|c|}
\hline \multirow{2}{*}{$\begin{array}{l}\text { Effect of } \\
\text { the drug } \\
\text { on }\end{array}$} & \multirow[t]{2}{*}{ Group } & \multirow[t]{2}{*}{$\mathbf{N}$} & \multicolumn{2}{|c|}{ Mean } & \multirow[t]{2}{*}{ Dif. } & \multirow{2}{*}{$\begin{array}{c}\text { \% of } \\
\text { Change }\end{array}$} & \multirow[t]{2}{*}{ SD } & \multirow[t]{2}{*}{ SE } & \multirow[t]{2}{*}{$\bar{T}$} & \multirow[t]{2}{*}{$\overline{\mathbf{P}}$} & \multirow[t]{2}{*}{ Remarks } \\
\hline & & & BT & $\mathbf{A T}$ & & & & & & & \\
\hline \multirow[t]{2}{*}{ Angmarda } & $\overline{\mathrm{A}}$ & 30 & 2.23 & 0.00 & 2.23 & 100 & 0.63 & 0.4 & 19.54 & $<0.001$ & H.S. \\
\hline & B & 30 & 2.13 & 0.07 & 2.07 & 96.88 & 0.64 & 0.12 & 17.70 & $<0.001$ & H.S. \\
\hline \multirow[t]{2}{*}{ Aruchi } & $\bar{A}$ & 30 & 1.57 & 0.00 & 1.57 & 100 & 0.63 & 0.11 & 13.71 & $<0.001$ & H.S. \\
\hline & $\overline{\mathrm{B}}$ & 30 & 1.57 & 0.00 & 1.57 & 100 & 0.57 & 0.10 & 15.10 & $<0.001$ & H.S. \\
\hline \multirow[t]{2}{*}{ Trishna } & $\overline{\mathrm{A}}$ & 30 & 0.93 & 0.10 & 0.83 & 89.29 & 0.46 & 0.08 & 9.90 & $<0.001$ & H.S. \\
\hline & $\bar{B}$ & 30 & 0.80 & 0.03 & 0.77 & 95.83 & 0.43 & 0.08 & 9.76 & $<0.001$ & H.S. \\
\hline \multirow[t]{2}{*}{ Alasya } & $\bar{A}$ & 30 & 1.33 & 0.00 & 1.33 & 100 & 0.48 & 0.09 & 15.23 & $<0.001$ & H.S. \\
\hline & $\bar{B}$ & 30 & 1.17 & 0.03 & 1.13 & 97.14 & 0.35 & 0.06 & 17.95 & $<0.001$ & H.S. \\
\hline \multirow[t]{2}{*}{ Gaurav } & $\overline{\mathrm{A}}$ & 30 & 2.27 & 0.00 & 2.27 & 100 & 0.52 & 0.10 & 23.84 & $<0.001$ & $\overline{\text { H.S. }}$ \\
\hline & $\bar{B}$ & 30 & 1.83 & 0.00 & 1.83 & 100 & 0.46 & 0.08 & 21.78 & $<0.001$ & H.S. \\
\hline \multirow[t]{2}{*}{ Jvara } & $\bar{A}$ & 30 & 1.37 & 0.10 & 1.27 & 92.68 & 0.45 & 0.08 & 15.43 & $<0.001$ & H.S. \\
\hline & B & 30 & 1.20 & 0.07 & 1.13 & 94.44 & 0.43 & 0.08 & 14.30 & $<0.001$ & H.S. \\
\hline \multirow[t]{2}{*}{ Apaka } & $\bar{A}$ & 30 & 1.90 & 0.00 & 1.90 & 100 & 0.55 & 0.10 & 19.00 & $<0.001$ & H.S. \\
\hline & $\overline{\mathrm{B}}$ & 30 & 1.80 & 0.10 & 1.70 & 94.44 & 0.47 & 0.09 & 19.98 & $<0.001$ & H.S. \\
\hline \multirow{2}{*}{$\begin{array}{c}\text { Shoonta } \\
\text { Anganam }\end{array}$} & $\bar{A}$ & 30 & 2.03 & 0.07 & 1.96 & 96.72 & 0.41 & 0.08 & 26.03 & $<0.001$ & H.S. \\
\hline & B & 30 & 1.50 & 0.07 & 1.43 & 95.56 & 0.50 & 0.09 & 15.58 & $<0.001$ & H.S. \\
\hline
\end{tabular}

Table No 2: (Effect of drug on general symptoms)

\begin{tabular}{|c|c|c|c|c|c|c|c|c|c|c|c|}
\hline \multirow{2}{*}{$\begin{array}{l}\text { Effect of the } \\
\text { drug on }\end{array}$} & \multirow[t]{2}{*}{ Group } & \multirow[t]{2}{*}{$\mathbf{N}$} & \multicolumn{2}{|c|}{ Mean } & \multirow[t]{2}{*}{ Dif. } & \multirow{2}{*}{$\begin{array}{c}\text { \% of } \\
\text { Change }\end{array}$} & \multirow[t]{2}{*}{ SD } & \multirow[t]{2}{*}{ SE } & \multirow[t]{2}{*}{$\mathbf{T}$} & \multirow[t]{2}{*}{$\mathbf{P}$} & \multirow[t]{2}{*}{ Remarks } \\
\hline & & & BT & AT & & & & & & & \\
\hline \multirow[t]{2}{*}{ Sandhishool } & $\overline{\mathrm{A}}$ & 30 & 2.43 & 0.63 & 1.80 & 73.97 & 0.71 & 0.13 & 13.80 & $<0.001$ & H.S. \\
\hline & $\mathrm{B}$ & 30 & 2.07 & 0.13 & 1.93 & 93.55 & 0.37 & 0.07 & 29.00 & $<0.001$ & H.S. \\
\hline \multirow{2}{*}{ Sandhigraha } & $\bar{A}$ & 30 & 2.50 & 0.13 & 2.47 & 94.67 & 0.61 & 0.11 & 21.08 & $<0.001$ & H.S. \\
\hline & $\mathrm{B}$ & 30 & 2.10 & 0.10 & 2.00 & 95.24 & 0.53 & 0.10 & 20.86 & $<0.001$ & H.S. \\
\hline \multirow{2}{*}{$\begin{array}{l}\text { Sandhisparsha } \\
\text { Asahyata }\end{array}$} & $\overline{\mathrm{A}}$ & 30 & 1.93 & 0.43 & 1.50 & 77.59 & 0.57 & 0.10 & 14.35 & $<0.001$ & H.S. \\
\hline & B & 30 & 1.43 & 0.07 & 1.37 & 95.35 & 0.49 & 0.09 & 15.27 & $<0.001$ & H.S. \\
\hline
\end{tabular}


The effect of trial drug on RA factor, ASO titre and CRP was found to be highly significant $(\mathrm{p}<0.001)$ both in group A as well as in group B, (Table no- 3)

Table No 3: Effect of drug on objective parameters

\begin{tabular}{|c|c|c|c|c|c|c|c|c|c|c|c|}
\hline \multirow{2}{*}{$\begin{array}{c}\text { Effect of } \\
\text { the drug } \\
\text { on }\end{array}$} & \multirow[t]{2}{*}{ Group } & \multirow[t]{2}{*}{$\mathbf{N}$} & \multicolumn{2}{|c|}{ Mean } & \multirow[t]{2}{*}{ Dif. } & \multirow{2}{*}{$\begin{array}{c}\% \text { of } \\
\text { Change }\end{array}$} & \multirow[t]{2}{*}{ SD } & \multirow[t]{2}{*}{$\overline{\text { SE }}$} & \multirow[t]{2}{*}{$\mathbf{T}$} & \multirow[t]{2}{*}{$\overline{\mathbf{P}}$} & \multirow[t]{2}{*}{ Remark } \\
\hline & & & $\overline{\text { BT }}$ & $\mathbf{A T}$ & & & & & & & \\
\hline \multirow[t]{2}{*}{ RA Factor } & $\overline{\mathrm{A}}$ & 30 & 39.92 & 22.75 & 16.50 & 41.33 & 19.59 & 3.58 & 4.61 & $<0.001$ & H.S. \\
\hline & $\bar{B}$ & 30 & 24.55 & 9.75 & 14.81 & 60.30 & 30.77 & 5.62 & 2.64 & $<0.01$ & H.S. \\
\hline \multirow{2}{*}{$\begin{array}{l}\text { CRP (C- } \\
\text { reactive } \\
\text { protein) }\end{array}$} & $\overline{\mathrm{A}}$ & 30 & 11.37 & 6.59 & 4.65 & 40.89 & 5.24 & $\overline{0.96}$ & 4.86 & $<0.001$ & H.S. \\
\hline & $\bar{B}$ & 30 & 15.34 & 5.92 & $\overline{9.42}$ & 61.42 & 22.36 & 4.08 & 2.31 & $<0.10$ & H.S. \\
\hline \multirow{2}{*}{$\begin{array}{l}\text { ASO Titre } \\
\text { (Anti } \\
\text { streptolysin } \\
\text { O) }\end{array}$} & $\bar{A}$ & 30 & 115.72 & 99.87 & 15.22 & 13.15 & 17.51 & 3.20 & 4.76 & $<0.10$ & H.S. \\
\hline & $\bar{B}$ & 30 & 101.91 & 68.46 & 33.45 & 32.82 & 105.83 & 19.32 & 1.73 & $>0.05$ & N.S. \\
\hline
\end{tabular}

\section{Discussion}

Maximum number of patients belonged to the age group of 41-50 years, which shows its predominance in the middle age group. This data is slightly in accordance with the modern findings, that the onset is most frequent during the fourth and fifth decades of life with $80 \%$ of all patients developing disease between the age of 35-50 years. In this study, majority of the patients were female as compared to male. Textual references also reflect the predominance of rheumatoid arthritis in females. In this study, most of the patients had impaired agni, with 55 patients $(91.67 \%)$ exhibiting mandagni, this mandagni leads to formation of ama (basis pathological unit) and mandagni also leads to mooda vata (impair anuloman of vata). Among 60 patients, 58(96. 67\%) patients exhibiting constipated bowel because mandagni decrease the force and action of saman vayu and apana vayu. In this study, 17 patients (28. 33\%) had krura kostha, 61. $67 \%$ had madhyam kostha, confirming dominance of either vata or kapha or both at kostha level in Amavata patients. These data also support the etiology of Amavata, mentioned in classics. Bhallatakadi churna comprises of Haritaki, Bhallatak, Tila and Guda. Haritaki having properties like amapachan, sroto vibandhanashaka and dosha anulomana. Bhallataka having tikshna and ushna guna, anuloman, deepan, pachan properties helps in stimulating jatharagni. Krishna Til causing agnipustikrit and kaphapitta nashak properties which are antagonistic to Ama and is very much required in the conditions like Amavata. (6) Guda having properties like anabhishandi and agnipushtikrita helps in ameliorating the symptoms of A mavata. Also in group B (Bhallataka guggul), guggul is having sukshma, tikshna and sara properties which is sufficient for the deep penetration of both the srotas resulting in pacifying the symptom of Amavata and also play an important role in breaking the pathogenesis of disease Amavata.

\section{Conclusion}

Lastly, it can be concluded that Amavata looks similar to Rheumatoid Arthritis in its clinical appearance. Bhallatak Guggulu Yoga mentioned in Yogaratnakar showed a substantial relief in all parameters whether subjective or clinical of the Amavata supporting its anti-inflammatory and anti arthritic action. Present study reflects that both regimens -Bhallatakadi churna with guda and Bhallatak guggulu, have given very good relief in signs and symptoms of Amavata, but in group B who received Bhallatak Guggulu showed faster and better improvement.

\section{References}

1. Upadhyaya Y. N., Sanskrit Commentary by Sri Vijayarakshita and Sri Kanthadatta. Madhava Nidana of Madhavakara, $3^{\text {rd }}$ edi. Varanasi; Chaukamba Sanskrit Series;1970, 105-110pg.

2. Arend W. P. Physiology of cytokine pathways in Rheumatoid arthritis. $4^{\text {th }}$ edi, 2001;101-106pg.

3. Dwarkanath. C. Introduction to Kayachikitsa. $3^{\text {rd }}$ edi. Varanasi; Bharati publication;1986;95pg

4. Vaidyaraj Datto Borkar. Yogaratnakar. $6^{\text {th }}$ edi. Pune; Gajanan book depot prakashan.

5. Raghumathanand K, Roma Mitra. Pharmacognosy of Indigenous drugs. $7^{\text {th }}$ edi. , New Delhi, CCRAS, 2001;

6. Brahmashankar Mishra. Bhavaprakash NighantuVidyotini Hindi Commentary, $6^{\text {th }}$ edi, Varanasi, Chaukambha Sanskrit Sansthana. 